\title{
PEMANFAATAN DEDAK PADI TERFERMENTASI UNTUK MENINGKATKAN PERTUMBUHAN BABI
}

\author{
MAHARDIKA I G., DAN I W. SUDIASTRA \\ Fakultas Peternakan, Universitas Udayana \\ e-mail: mahardikagede@yahoo.com
}

\begin{abstract}
ABSTRAK
Penelitian telah dilakukan yang bertujuan untuk mengetahui pengaruh pemberian dedak padi terfermentasi terhadap penampilan babi. Penelitian menggunakan Rancangan Acak Lengkap dengan 4 perlakuan dan 4 ulangan. Keempat perlakuan tersebut adalah Perlakuan A: Babi yang mendapat ransum mengandung dedak padi tanpa fermentasi, perlakuan B: Babi yang mendapat ransum mengandung dedak padi dan $25 \%$ dedak padinya terfermentasi, perlakuan C: Babi yang mendapat ransum mengandung dedak padi dan 50\% dedak padinya terfermentasi, dan perlakuan D: Babi yang mendapat ransum mengandung dedak padi dan 100\% dedak padinya terfermentasi. Variabel yang diamati meliputi: konsumsi pakan, pertumbuhan, efisiensi penggunaan pakan, kecernaan bahan kering pakan dan kecernaan nutrient yang meliputi kecernaan protein, serat kasar, lemak dan energi tercerna (DE). Dari hasil penelitian ini dapat disimpulkan bahwa penggunaan dedak padi terfermentasi pada ransum babi dapat meningkatkan pertumbuhan babi dan meningkatkan efisiensi penggunaan ransum.
\end{abstract}

Kata kunci: dedak padi, fermentasi, babi, pertumbuhan.

\section{UTILIZATION OF FERMENTED RICE BRAN TO INCREASED PERFORMANCE OF PIG}

\begin{abstract}
The research has been conducted which aims to analisys the effect of fermented rice bran to pig performance. Completly Randomize Design with 4 treatments and 4 replicates were used in this research. Treatment A: pig given ration containing rice bran without fermentation, treatment B: pig given ration containing $25 \%$ fermented rice bran, treatment C: pig given ration containing 50\% fermented rice bran, and treatment D: pig given ration containing $100 \%$ fermented rice bran. Observed variabels are: feed consumption, average daily gain, feed convertion ratio, digestability of nutrient dan digestible energy (DE). Results of this study concluded the used of fermented rice bran increased of growth and feed efficiency.
\end{abstract}

Keywords: rice bran, fermetation, pig, growth

\section{PENDAHULUAN}

Kebutuhan daging di Indonesia terus meningkat sejalan dengan meningkatnya jumlah penduduk dan kesadaran masyarakat akan pentingnya peran protein hewani. Pada tahun 2012 kebutuhan daging di Indonesia mencapai 490.000 ton, dan yang bisa dipenuhi oleh produksi ternak di dalam negeri hanya berkisar $82 \%$, sedangkan sisanya dari import. Diharapkan import daging tidak lebih dari 10\% dari kebutuhan daging nasional. Ini artinya 90\% produksi daging harus dapat dipenuhi dari produksi ternak di dalam negeri. Untuk mencapai ini diperlukan peningkatan produksi ternak yang salah satunya adalah dengan meningkatkan populasi ternak.

Babi merupakan salah satu jenis ternak potong yang sudah beradaptasi dengan lingkungan di daerah tropis. Hal ini tercermin dari tingginya tingkat reproduksi karena babi bersifat prolifik yaitu dapat menghasilkan anak yang cukup banyak dalam satu kali kelahiran. Di samping itu babi punya sifat yang tidak terlalu selektif terhadap pakan yang tersedia, sehingga babi sangat berpotensi untuk ditingkatkan produktifitasnya. Babi juga mempunyai nilai karkas dan kualitas daging yang cukup baik sehingga dapat diharapkan sebagai primadona penyedia daging di masa depan.

Dedak padi adalah salah satu limbah penggilingan padi yang merupakan salah satu bahan pakan utama 
untuk ternak babi, ketersediaannya cukup banyak dan tidak merupakan bahan makanan manusia sehingga sangat potensial sebagai bahan pakan ternak. Penggunaan dedak padi sebagai bahan pakan babi cukup tinggi yaitu mencapai 30 - 40\% di dalam ransum. Hal ini disebabkan karena beberapa factor antara lain, produksinya yang relatif banyak, tidak dimanfaatkan sebagai bahan makanan manusia, harga relatif murah serta kandungan nutriennya relatif baik sebagai pakan ternak. Sebagai bahan pakan ternak, dedak padi memiliki kelemahan yaitu kandungan serat kasarnya cukup tinggi yaitu mencapai $13 \%$. Bila dilihat dari kandungan nutrient yang lain, dedak sangat potensial karena mengandung protein $12-13,5 \%$ dan kandungan energinya mencapai $1890 \mathrm{~K} . \mathrm{kal} / \mathrm{kg}$ (Rasyaf, 2002). Di samping itu dedak juga mengandung asam fitat yang dapat mengikat mineral sehingga penyerapan mineral akan terganggu.

Dalam ransum babi, dedak digunakan sampai 30 $40 \%$ dalam ransum. Penggunaan yang tinggi tersebut dapat mengganggu penyerapan nutrient karena serat kasarnya yang tinggi. Untuk mengurangi pengaruh negative tersebut perlu dilakukan pengolahan yang salah satunya dengan melakukan fermentasi. Fermentasi pada dedak dapat menurunkan serat kasar, meningkatkan kandungan protein serta dapat meningkatkan kecernaan pakan. Bidura (2012) yang meneliti pemanfaatan dedak padi terfermentasi dengan Saccharomyses cerevisiae pada ransum itik mendapatkan bahwa terjadi peningkatan performans itik tersebut. Tujuan penelitian ini adalah untuk mengetahui kecernaan nutrient dari ransum yang mengandung dedak padi terfermentasi serta untuk mengetahui penampilan/produktivitas babi yang mendapat ransum mengandung dedak padi terfermentasi.

\section{MATERI DAN METODE}

Babi yang digunakan dalam penelitian ini adalah babi Landrace lepas sapih yang sudah dikebiri umur 2 bulan dengan berat badan rata-rata $15 \mathrm{~kg}$. sebanyak 16 ekor. Sebelum digunakan untuk penelitian babi terlebih dahulu divaksin dengan vaksin SE, kolera dan diberikan obat cacing.

Kandang yang digunakan adalah kandang individu sebanyak 16 petak, tiap petak dilengkapi dengan tempat pakan. Untuk air minumnya disediakan dalam ember untuk masing-masing babi. Atap kandang terbuat dari genting, sementara lantai kandang, dan tempat pakan terbuat dari beton. Ransum dan air minum diberikan secara ad-libitum.

Penelitian dilakukan di stasiun penelitian Fakultas Peternakan, Universitas Udayana, analisa proksimat dilakukan di Laboratorium Makanan Ternak Fakultas
Peternakan Universitas Udayana

Ransum yang deberikan terdiri dari bahan-bahan konsentrat komersial, jagung kuning dan dedak padi dengan komposisi 30\% konsentrat, 30\% dedak padi dan $40 \%$ jagung giling. Komposisi bahan penyusun ransum percobaan disajikan pada Tabel 1

Tabel 1. Komposisi bahan penyususn ransum percobaan

\begin{tabular}{lcccc}
\hline & \multicolumn{4}{c}{ Ransum Perlakuan } \\
\cline { 2 - 5 } \multicolumn{1}{c}{ Bahan Pakan (\%) } & $\mathrm{A}$ & $\mathrm{B}$ & $\mathrm{C}$ & $\mathrm{D}$ \\
\hline Konsentrat komersial & 30 & 30 & 30 & 30 \\
Dedak tidak fermentasi & 30 & 22,5 & 15 & 0 \\
Dedak fermentasi & 0 & 7,5 & 15 & 30 \\
Jagung giling & 40 & 40 & 40 & 40 \\
\hline
\end{tabular}

Penelitian menggunakan Rancangan Acak Lengkap dengan 4 perlakuan dan 4 ulangan dan masing-masing unit percobaan terdiri dari 1 ekor babi. Keempat perlakuan tersebut adalah:

A : Babi yang mendapat ransum mengandung dedak padi tanpa fermentasi

B : Babi yang mendapat ransum mengandung dedak padi dan $25 \%$ dedak padinya terfermentasi

$\mathrm{C}$ : Babi yang mendapat ransum mengandung dedak padi dan 50\% dedak padinya terfermentasi

$\mathrm{D}$ : Babi yang mendapat ransum mengandung dedak padi dan $100 \%$ dedak padinya terfermentasi.

Variabel yang diamati meliputi: konsumsi pakan, pertumbuhan, efisiensi penggunaan pakan, kecernaan bahan kering pakan dan kecernaan nutrient yang meliputi kecernaan protein dan serat kasar. Konsumsi pakan ditentukan dengan cara mengurangi jumlah pakan yang diberikan dengan sisa makanan yang dihitung setiap hari. Pertumbuhan ternak dihitung dengan cara menimbang babi setiap minggu, kemudian kenaikan berat badan dihitung dengan mengurangi berat badan akhir dengan berat badan awal dibagi dengan lama penelitian. Kecernaan bahan kering ransum ditentukan dengan metode koleksi total selama 1 minggu, dengan masa adaptasi selama 1 minggu (Tillman, et al. 1998). Kecernaan pakan yang dihitung meliputi, kecernaan bahan kering, kecernaan bahan organik, kecernaan protein, kecernaan serat kasar dan kecernaan lemak. Efisiensi penggunaan pakan (FCR) diperoleh dengan membagi jumlah pakan yang dikonsumsi dengan pertambahan berat badan

\section{HASIL DAN PEMBAHASAN}

\section{Kandungan Nutrien Ransum}

Ransum yang mengandung dedak padi yang terfermentasi mengalami peningkatan kandungan protein kasar serta terjadi penurunan kandungan 
serat kasar (Tabel 2). Meningkatnya jumlah dedak terfermentasi dalam ransum akan menyebabkan peningkatan kadar protein kasar. Ransum yang tidak mengandung dedak terfermentasi, kandungan protein kasarnya $15,25 \%$, sedangkan ransum yang mengandung dedak terfermentasi 50\%, 75\% dan 100\% kandungan protein kasarnya masing-masing 16,65\%, 17,10\% dan $18,31 \%$. Peningkatan kandungan protein kasar ini disebabkan oleh adanya pertumbuhan mikroba yang terkandung dalam dedak terfermentasi. Promono et al. (2007) mendapatkan bahwa terjadi peningkatan kadar gula reduksi dan protein terlarut dari degradasi komponen karbohidrat dan protein pada proses fermentasi. Proses fermentasi ini akan menyebabkan peningkatan proses perombakan struktur yang komplek menjadi struktur yang lebih sederhana sehingga lebih mudah dicerna dalam saluran pencernaan.

Bidura et al. (2008) menyatakan bahwa keuntungan dari fermentasi adalah mengubah makromelekul protein menjadi mikromelokul yang mudah dicerna oleh ternak. Selanjutnya dikatakan, di samping dapat meningkatkan kandungan protein dalam ransum, proses fermentasi dapat meningkatkan kecernaan ransum.

Tabel 2. Kandungan nutrient ransum yang mengandung dedak padi terfermentasi

\begin{tabular}{lrrrr}
\hline \multirow{2}{*}{ Nutrien (\%) } & \multicolumn{4}{c}{ Ransum } \\
\cline { 2 - 5 } & \multicolumn{1}{c}{ A } & \multicolumn{1}{c}{ B } & \multicolumn{1}{c}{ C } & \multicolumn{1}{c}{ D } \\
\hline Bahan kering & 89,05 & 87,67 & 89,16 & 87,56 \\
Bahan organik & 92,79 & 93,77 & 92,00 & 94,03 \\
Protein Kasar & 15,25 & 16,64 & 17,10 & 18,31 \\
Serat kasar & 6,09 & 4,57 & 5,32 & 3,98 \\
Lemak & 6,09 & 6,27 & 7,19 & 6,09 \\
BETN & 54,41 & 53,95 & 51,54 & 53,21 \\
TDN & 70,23 & 73,77 & 73,15 & 74,86 \\
\hline
\end{tabular}

Keterangan:

1). A: Ransum mengandung dedak padi tanpa fermentasi ( $100 \%$ dedak tidak fermentasi) B: Ransum mengandung dedak padi terfermentasi $50 \%$

C: Ransum mengandung dedak padi terfermentasi $75 \%$

D: Ransum mengandung dedak padi terfermentasi $100 \%$

Fermentasi dedak padi juga menyebabkan terjadinya penurunan serat kasar pada bahan makanan. Ransum yang mengandung 100\% dedak tidak terfermentasi kandungan serat kasarnya 6,09\% sedangkan ransum yang mengandunga 100\% dedak terfermentasi kandungan serat kasarnya menurun menjadi 3,98\%. Penurunan kandungan serat kasar ini disebabkan karena proses fermentasi merombak ikatan lignoselulose sehingga senyawa-senyawa karbohidrat komplek seperti serat kasar akan terurai menjadi karbohidrat sederhana yang lebih mudah larut. Vallie et al (1992) menyatakan bahwa kapang dan khamir sebagai fermentor mempunyai kemampuan menghasilkan enzim peroksidase ekstraseluler berupa lignin peroksidase dan mangan peroksidase yang dapat memecah ikatan-ikatan pada serat sehingga menjadi senyawa yang lebih sederhana.

Bidura (2012) melakukan penelitian dengan melakukan fermentasi terhadap dedak padi mendapatkan bahwa dedak padi yang difermentasi mengalami penurunan kadar serat kasar, meningkatkan kandungan protein kasar dan peningkatan kandungan energi bruto dedak tersebut. Di samping itu didapatkan juga bahwa kecernaan bahan kering dedak padi terfermentasi mengalami peningkatan dari $62,43 \%$ menjadi $69,13 \%$, sedangkan kecernaan bahan organik dan kecernaan proteinnya meningkat masing-masing dari 63,06\% menjadi $69,54 \%$ dan $67,72 \%$ menjadi $70,28 \%$.

\section{Penampilan Babi}

Kenaikan berat badan (PBB) babi yang mendapat ransumyangmengandungdedakpaditidakterfermentasi (perlakuan A) adalah $0,49 \mathrm{~kg} / \mathrm{h}$, sedangkan babi yang mendapat ransum yang mengandung 50\% dedak padi terfermentasi (perlakuan B) adalah $0,54 \mathrm{~kg} / \mathrm{h}$, babi yang mendapat ransum mengandung $75 \%$ dedak padi terfermentasi (perlakuan C) adalah $0,58 \mathrm{~kg} / \mathrm{h}$ dan babi yang mendapat ransum mengandung $100 \%$ dedak padi terfermentasi (perlakuan D) adalah $0,54 \mathrm{~kg} / \mathrm{h}$ (Tabel 3). Secara statistik babi yang mendapat ransum yang mengandung $75 \%$ dan $100 \%$ dedak padi terfermentasi lebih besar dari babi yang mendapat ransum dedak padi yang tidak terfermentasi $(\mathrm{P}<0,05)$.

Peningkatan pertumbuhan babi yang mendapat ransum mengandung dedak padi terfermentasi disebabkan karena fermentasi dedak padi akan menyebabkan perombakan senyawa komplek menjadi senyawa yang lebih sederhana sehingga kecernaan pakan menjadi lebih tinggi. Meningkatnya kecernaan pakan akan menyebabkan ternak mendapat nutrien yang lebih banyak sehingga pertumbuhannya lebih cepat. Hasil ini sejalan dengan yang didapatkan oleh Bidura (2012) yang meneliti penggunaan dedak padi terfermentasi pada ternak itik yang memperoleh hasil bahwa kenaikan berat badan itik yang diberikan ransum mengandung 30\% dedak tidak fermentasi adalah $739,62 \mathrm{~g} / \mathrm{h}$, sedangkan itik yang diberikan ransum yang mengandung 30\% dedak padi terfermentasi adalah $886,18 \mathrm{~g} / \mathrm{h} .(\mathrm{P}<0,05)$.

Konsumsi ransum babi yang mendapat perlakuan A adalah $1,27 \mathrm{~kg} / \mathrm{h}$, sedangkan konsumsi ransum pada perlakuan $\mathrm{B}, \mathrm{C}$ dan $\mathrm{D}$ ada kecenderungan meningkat namun secara statistik tidak berbeda dengan perlakuan A ( $\mathrm{P}>0,05)$. Dengan konsumsi ransum yang semakin meningkat tersebut akan menyebabkan babi mendapatkan nutrien dengan jumlah yang lebih tinggi. 
Tabel 3. Penampilan babi yang mendapat pakan yang mengandung dedak padi terfermentasi

\begin{tabular}{lrrrr}
\hline \multirow{2}{*}{ Variabel } & \multicolumn{4}{c}{ Perlakuan 1$)$} \\
\cline { 2 - 5 } & \multicolumn{1}{c}{$\mathrm{A}$} & \multicolumn{1}{c}{$\mathrm{B}$} & \multicolumn{1}{c}{$\mathrm{C}$} & \multicolumn{1}{c}{$\mathrm{D}$} \\
\hline Kenaikan berat badan $(\mathrm{kg} / \mathrm{h})$ & $0,49 \mathrm{a}$ & $0,54 \mathrm{ab}$ & $0,58 \mathrm{~b}$ & $0,54 \mathrm{a}$ \\
Konsumsi BK $(\mathrm{kg} / \mathrm{h})$ & $1,31 \mathrm{a}$ & $1,38 \mathrm{a}$ & $1,46 \mathrm{a}$ & $1,36 \mathrm{a}$ \\
Konsumsi bahan organik $(\mathrm{kg} / \mathrm{h})$ & $1,21 \mathrm{a}$ & $1,29 \mathrm{a}$ & $1,34 \mathrm{a}$ & $1,28 \mathrm{a}$ \\
Konsumsi protein $(\mathrm{g} / \mathrm{h})$ & $199,78 \mathrm{a}$ & $229,63 \mathrm{~b}$ & $249,66 \mathrm{~b}$ & $249,02 \mathrm{~b}$ \\
Konsumsi serat kasar $(\mathrm{g} / \mathrm{h})$ & $79,77 \mathrm{a}$ & $63,07 \mathrm{ab}$ & $71,29 \mathrm{a}$ & $54,13 \mathrm{~b}$ \\
FCR & $2,79 \mathrm{a}$ & $2,56 \mathrm{~b}$ & $2,51 \mathrm{~b}$ & $2,51 \mathrm{~b}$ \\
\hline
\end{tabular}

Keterangan:

1). A: Babi yang mendapat ransum mengandung dedak padi tanpa fermentasi B: Babi yang mendapat ransum mengandung dedak padi terfermentasi $50 \%$

C: Babi yang mendapat ransum mengandung dedak padi terfermentasi $75 \%$

D: Babi yang mendapat ransum mengandung dedak padi terfermentasi $100 \%$

Konsumsi bahan organik tidak mengalami peningkatan pada ransum yang mengandung dedak padi terfermentasi $(\mathrm{P}>0,05)$, tetapi terjadi peningkatan konsumsi protein dari 199,78 g/h menjadi $249 \mathrm{~g} / \mathrm{h}$ pada ransum yang mengandung dedak padi terfermentasi. Konsumsi serat kasar terjadi penurunan dari 79,77 g/h menjadi 54,13 g/h $(\mathrm{P}<0,05)$. Penurunan konsumsi serat ini disebabkan karena terjadi penurunan kandungan serat kasar pada ransum yang mengandung dedak padi terfermentasi.

Efisiensi penggunaan pakan yang dihitung dari perhitungan FCR mendapatkan bahwa penggunaan dedak padi terfermentasi dalam ransum dapat meningkatkan efisiensi penggunaan ransum. Hal ini tercermin dari semakin menurunnya nilai FCR pada babi yang mendapat ransum mengandung dedak padi terfermentasi $(\mathrm{P}<0,05)$. FCR pada babi perlakuan A adalah 2,79, sedangkan nilai FCR pada perlakuak B, C dan D berturut-turut adalah 2,56; 2,51 dan 2,51.

\section{Kecernaan Pakan}

Pengukuran kecernaan pakan dilakukan dengan metode koleksi total yaitu dengan mengukur jumlah konsumsi pakan dan menampung jumlah kotoran dalam kurun waktu yang sama yairu selama satu minggu. Selanjutnya akan dilakukan analisis terhadap kandungan nutrien ransum dan kandungan nutrien dari kotoran. Dari data tersebut dapat dihitung kecernaan bahan kering ransum dan kecernaan nutrien.

Kecernaan bahan bahan kering dan kecernaan bahan organik ransum mengalami peningkatan dengan meningkatnya penggunaan dedak padi terfermentasi. Ransum yang tidak mengandung dedak padi terfermentasi mempunyai kecernaan bahan organik $62,14 \%$ sedangkan ransum yang mengandung $100 \%$ dedak padi terfermentasi kecernaan bahan keringnya 67,53\% (Tabel 4). Sejalan dengan kecernaan bahan kering kecernaan bahan organik juga meningkat dari $66,84 \%$ menjadi $68,24 \%$ pada ransum dengan $100 \%$ dedak padinya terfermentasi. Peningkatan kecernaan ini disebabkan karena pada dedak padi terfermentasi terjadi perombakan senyawa-senyawa komplek menjadi senyawa yang lebih sederhana sehingga mempunyai kelarutan yang lebih tinggi. Dengan kelarutan yang lebih tinggi maka kecernaannya juga mengalami peningkatan. Hasil penelitian ini sejalan dengan pendapat Hendraningsih (2005) yang menyatakan bahwa fermentasi akan merombak struktur senyawa menjadi lebih sederhana sehingga lebih mudah dicerna oleh ternak.

Tabel 4. Kecernaan nutrien ransum yang mengandung dedak padi terfermentasi

\begin{tabular}{lcccc}
\hline \multirow{2}{*}{ Variabel } & \multicolumn{4}{c}{ Perlakuan 1) } \\
\cline { 2 - 5 } & A & B & C & D \\
\hline Kecernaan bahan kering (\%) & $62,14 \mathrm{a}$ & $64,24 \mathrm{ab}$ & $65,02 \mathrm{~b}$ & $67,53 \mathrm{~b}$ \\
Kecernaan bahan organik (\%) & $66,84 \mathrm{a}$ & $67,38 \mathrm{ab}$ & $67,54 \mathrm{ab}$ & $68,24 \mathrm{~b}$ \\
Kecernaan protein (\%) & $67,15 \mathrm{a}$ & $68,33 \mathrm{ab}$ & $69,61 \mathrm{~b}$ & $69,90 \mathrm{~b}$ \\
\hline
\end{tabular}

Keterangan:

1). A: Babi yang mendapat ransum mengandung dedak padi tanpa fermentasi

B: Babi yang mendapat ransum mengandung dedak padi terfermentasi $50 \%$

C: Babi yang mendapat ransum mengandung dedak padi terfermentasi $75 \%$

D: Babi yang mendapat ransum mengandung dedak padi terfermentasi $100 \%$

Di samping terjadi peningkatan kecernan bahan kering dan bahan organik juga terjadi peningktan kecernaan protein ransum. Ransum yang mengandung dedak padi tanpa fermentasi kecernaan proteinnya $67,15 \%$, sedangkan ransum yang mengandung $100 \%$ dedak padi terfermentasi, kecernaan proteinnya meningkat menjadi 69,90\%.

\section{SIMPULAN}

Dari hasil penelitian ini dapat disimpulkan bahwa:

1. Penggunaan dedak padi terfermentasi pada ransum babi dapat meningkatkan kandungan protein dan TDN ransum, sedangkan terjadi penurunan kandungan serat kasar.

2. Penggunaan dedak padi terfermentasi dalam ransum babi meningkatkan kecernaan bahan organik, kecernaan bahan kering dan kecernaan protein pakan.

3. Terjadi peningkatan pertumbuhan babi yang mendapat ransum mengandung dedak padi terfermentasi.

4. Ransum yang mengandung dedak padi terfermentasi mempunyai efisiensi penggunaan ransum yang lebih baik, yang ditunjukan oleh penurunan FCR ransum. 


\section{DAFTAR PUSTAKA}

Bali dalam Angka. 2013. Badan Pusat Statistik Provinsi Bali. Penerbit BPS Provinsi Bali.

Bidura, I.G.N.G. 2012. Pemanfaatan Khamir Saccharomyces cerevisiae yang Diisolasi dari Ragi Tape untuk Meningkatkan Nilai Nutrisi Dedak Padi dan Penampilan Itik Bali Jantan. Disertasi . Program Pascasarjana, Universitas Udayana.

Bidura, I.G.N.G. T.I. Putri, dan I.B. Gaga Partama, 2008. Pengaruh pemberian ransum terfermentasi terhadap pertambahan berat badan, karkas dan jumlah lemak abdomen pada itik bali. Jurnal Pengembangan Peternakan Tropis, Vol. 33 (4): 274-281

Budaarsa, K. 1997. Kajian Penggunaan Rumput Laut dan Sekam Padi Sebagai Sumber Serat Dalam Ransum Untuk Menurunkan Kadar Lemak Karkas dan Kolesterol Daging Babi. Disertasi. Program Pascasarjana Institut Pertanian Bogor.

Egedius, L. L., K. Budaarsa, K. dan I G.Mahardika. (2014). Penampilan Ternak Babi yang Diberikan Pakan Mengandung Tepung Bekicot (Achatina fulica) Sebagai Pengganti Tepung Ikan. Prosiding. Seminar Nasional Ternak Babi, Denpasar 2014.

Hendraningsih, L. 2005. Evaluasi Daya Hidup Bakteri Selulolitik dalam Media Pembawa Polard. Laporan penelitian Bidang Ilmu. Universitas Muhamaddiyah Malang.

Idouraine, A., M. J. Khan and C.W. Weber. 1996. In-Vitro binding capacity of wheat bran, rice bran and oat fiber for $\mathrm{Ca}, \mathrm{Mg}, \mathrm{Cu}$ and $\mathrm{Zn}$ alone and in different combinations. J. Agric.Food Chem. 44: 206-2072.

Igbal, M. 2011. Antara Kecerdasan, Kemakmuran dan Prioritas Pembangunan Peternakan. http:// www. geraidinasingapura.com/. [Diunduh 14 Juni 2014].

Jaelani, A., W.G. Piliang, Suryahadi dan I. Rahayu, 2008. Hidrolisis bungkil inti sawit (Ellaeis guineesis, Jacq) oleh kapang Trichoderma reesei pendegradasi polisakarida manan. Animal Production Vol: 10(1): 42-49.

Pramono, Y.B., E.S. Rahayu, Suparno dan T. Utami. 2007. Perubahan mikrobiologis, fisik dan kimia cairan bakal petis daging selama fermentasi kering spontan. Jurnal Pengembangan Peternakan Tropis. Vol: 32 (4): 213-221.

Rasyaf, M. 2002. Bahan Makanan Unggas di Indonesia, Cetakan ke-9. Yoyakarta: Penerbit Kanisius.

Rasyaf, M. 2004. Seputar Makanan Ayam Kampung, Cetakan ke-8. Yogyakarta. Penerbit Kanisius.

Steel, R.G.D. and J.H. Torrie. 1989. Principles and Procedures of Statistics. $2^{\text {nd }}$ Edition. London: Mcgraw-Hill International Books Co.

Sumiati, 2005. Rasio Molar Asam Fitat: Zn untuk menentukan suplementasi $\mathrm{Zn}$ dan enzyme phytase dalam ransum berkadar asam fitat tinggi. Disertasi. Program Pascasarjana, Institut Pertanian Bogor.

Vallie, K., J. Barry, Brock, K.Dinesh and J.H. Michael. 1992. Degradation of 2.4 toluen by the lignin degradation fungi Phanerochaete chrysosporium. J. Appl and Env Microbial. 8: 221-228 